\title{
A Time Course Study of the Relative Cytotoxic Effects of Extracts of Different Types of Tobacco on Allium cepa Mitosis
}

\author{
Anusri Baneriee \\ Department of Botany, University of Calcutta, 35, Ballygunge Circular Road, \\ Calcutta-700 019, India
}

Accepted January 16, 1992

Habits associated with the use of tobacco are found world wide, with countless variations in the nature of the product used. The predominant use of tobacco is either by smoking or in the form of smokeless tobacco which is mainly used orally. Consumption of tobacco other than smoking has now become popular as an alternative to smoking, though the genetic risk to individuals for non-smoking tobacco is now well established (Stedmen 1968, Schmeltz and Hoffman 1977, Banerjee and Sharma 1979, Bandyopadhyay and Sharma 1980, Shapiro 1981, Stich and Stich 1982, Stich and Rosin 1984, IARC Monograph 1989).

The mutachromosomal and mutagenic effects of the tobacco extracts in water before thermal combustion is of special importance under Indian conditions, where a sizeable proportion of the population uses tobacco as chew or snuff with different additives but without smoking. The tobacco marketed in India have been shown to have high tar (19-27 mg) and high nicotine (1.00-1.4 mg) yeilds (WHO Tech Report Series 1983).

The present investigations were undertaken to study the effects of water souble extracts of different forms of tobacco preparations used in India on plant test system. The endopoints screened were the frequencies of cell division and chromosomal changes. The action was seen on both mitotic index and chromosome behaviour, using different dosages and different periods of treatment.

\section{Material}

Four different varieties of commonly used tobacco materials were tested. These included two varieties of Nicotiana tabacum L. leaves directly in the raw form. They were collected from the local market and designated according to their specific leaf shapes as 'round leaf' and 'long leaf'. The other two types of tobacco were ingredinets of bidi, a local smoking form and of cigarettes of a known commercial popular brand.

(i) Round leaf is a variety of Nicotiana tabacum L. cultivated in India, in Assam, West Bengal, Bihar, Uttar Pradesh and Punjab and used widely for smoking through water pipes i.e., hookah. Its common market name is 'Matihari' (The Wealth of India, 1972).

(ii) Long leaf is a variety of Nicotiana tabacum $\mathrm{L}$. used for chewing and snuff tobacco. The leaves are long with a thick midrib. It is cultivated in Bihar and South India. It is commonly known in the local market as the 'Khaini' tobacco.

(iii) Ingredients of Bidi, a form of smoked tobacco. It was collected directly from the local market, without the outer wrappings and consisted of chopped up pieces of tobacco leaves. This material is sun cured and processed mainly for bidi making.

(iv) Ingredients of Cigarette were collected from 'Charminar', a brand of common use among the heavy smokers. The material was taken out from the paper wrappings. It was the roasted form of tobacco leaf used in the cigarette.

The effects were observed on the plant system Allium cepa in vivo. Young bulbs with 
freshly grown root-tips were treated with the different chemicals directly and then allowed to recover.

\section{Method}

Aqueous solutions were prepared of the four different tobacco materials. Only the laminar portions of the leaves were separated from the veins dried in sunlight, and ground into powder. The ingredients of bidi and cigarette were taken out of their wrappings.

The powdered material or its ingredients were soaked in $100 \mathrm{ml}$ of distilled water and kept at room temperature for overnight. The extracts were filtered with Whatman Paper (No. 1) and the clear dark brown solutions were stored at $4^{\circ} \mathrm{C}$.

Bulbs of Allium cepa were sown in saw dust. After 2 days bulbs with fresh root tips from the same collection were used as test system (Grant 1982). They were washed and placed in the tobacco extracts of different concentrations calculated according to the fraction of $\operatorname{LD}_{50}$ of pure nicotine present as shown by acute exposure. 500,250 and $125 \mathrm{ppm}$. of the extract corresponded with $\mathrm{LD}_{50}$, acute and subchronic doses of nicotine were used.

Root-tips were excised after exposure and fixed in glacial acetic acid: absolute ethyl alcohol (1:2). The tips were removed after exposure for $1,2,3,4,5,6,12$ and $24 \mathrm{hr}$ and onwards till lethality ensued. The tips were stained in $(9: 1)$ aceto-orcein and squashed following the usual schedule (Sharma and Sharma 1980). Control sets were maintained simultaneously in distilled water.

About 5000 cells were scored for each smapling period per concentration. The numbers of dividing cells of various stages were recorded and the mitotic index was calculated.

The abnormalities observed in dividing cells were of two categories and were expressed as percentage of total dividing cells. Group I included effects due to spindle disturbances, such as laggards, tripolarity, sticky bridge and clumping. Group II types were lethal, shown by pycnosis and gross pulverisation. Frequencies of aberrant cells at different doses were compared statistically with control at the various durations.

\section{Results and discussion}

The data obtained has been summarised in Tables 1 to 4 with detail statistical 'Anova' between each type with different concentrations. Certain general trends can be observed by analysing these tables, which can be summarised as follows:

(i) Frequency of abnormal cells: the biri extract, at high concentrations, (500 ppm) differs significantly ( $1 \%$ level) from round leaf extract and cigarette extract.

Round leaf extract differs significantly from cigarette and long leaf extracts after acute treatment $(500 \mathrm{ppm})$. Cigarette leaf extract differs significantly at $1 \%$ level from long leaf extract the highest concentrations. With $250 \mathrm{ppm}$, percentage of abnormality differ significantly between all types extracts except between the extracts of long leaf and cigerette.

With $125 \mathrm{ppm}$, there is no significant difference between round leaf extract and cigarette extract. All other types differ significantly in frequency of abnormalities induced.

The abnormalities are directly dependent on the dose and duration of treatment. No breaks, unequal separation or lagging are found. No telophase was observed. Most of the cells affected were at metaphase indicating metaphase arrest. Stickiness at metaphase is the only abnormality found.

In all the cases the root-tips recovered gradually depending on the duration of treatment. Following treatment with high concentrations for $48 \mathrm{hr}$ in all the 4 types, root-tips did not recover. Percentage of abnormal cells decreased gradually with the duration of recovery 
period. The cells became gradually normal, with decrease clumping and stickiness. In all the cases there is a direct dose duration relationship on which the recovery of the root-tips is dependent. $96 \mathrm{hr}$ of treatment is lethal in all the cases. The mitotic index is not different from the control sets during the recovery in all the extracts. Polyploidy, multipolarity or unequal separations are not found. No high level of differences was found in the comparative effects of the 4 different extracts considering the rate of recovery.

Mitotic index indicated that certain concentrations of tobacco extract were mitotic in Allium cells. The round leaf extract and cigarette extract have higher range of mitotic frequency at significant level when compared with the control. Aqueous extract of Bidi and Khaini tobacco on the other hand showed a strong mitostatic effect in higher concentrations. However, in lower $125 \mathrm{ppm}$, the range of mitotic frequency was similar to that of control.

Table 1. FISHER ' $t$ ' values for comparison between total number of dividing cells in treatment and control sets of Allium cepa

\begin{tabular}{|c|c|c|c|c|c|c|c|c|}
\hline \multicolumn{9}{|c|}{ Formula used: $\left.t=\left(p_{1} \sim p_{2}\right) / \sqrt{\left(\frac{1}{n_{1}}+\frac{1}{n_{2}}\right)\left\{\frac{\left(n_{1}-1\right) s_{1}{ }^{2}+\left(n_{2}-1\right) s_{2}{ }^{2}}{n_{1}+n_{2}{ }^{-2}}\right.}\right\}$} \\
\hline $\begin{array}{l}\text { Different } \\
\text { concentration } \\
\text { (in ppm) }\end{array}$ & $\begin{array}{l}\text { Mean } \\
\text { of the } \\
\text { sample } \\
\left(p_{1}\right)\end{array}$ & $\begin{array}{c}\text { Standard } \\
\text { deviation } \\
\text { of the } \\
\text { sample } \\
\left(s_{1}\right)\end{array}$ & $\begin{array}{l}\text { Size of } \\
\text { the } \\
\text { sample } \\
\left(n_{1}\right)\end{array}$ & $\begin{array}{l}\text { Mean of } \\
\text { control } \\
\text { sample } \\
\left(p_{2}\right)\end{array}$ & $\begin{array}{l}\text { Standard } \\
\text { deviation } \\
\text { of control } \\
\text { sample } \\
\left(s_{2}\right)\end{array}$ & $\begin{array}{l}\text { Size of } \\
\text { control } \\
\text { sample } \\
\left(\mathrm{n}_{2}\right)\end{array}$ & $\begin{array}{c}\text { Degrees } \\
\text { of } \\
\text { freedom } \\
=\left(n_{1}+n_{2}-2\right)\end{array}$ & $\begin{array}{l}\text { Computed } \\
\text { Fishers ' } t \text { ' } \\
\text { values }\end{array}$ \\
\hline \multicolumn{9}{|c|}{ Treated with Bidi extract } \\
\hline 1.25 & 2.04 & 0.71 & 10 & & & & 19 & 4.47 \\
\hline 2.5 & 2.41 & 0.725 & 9 & 3.65 & 0.915 & 11 & 18 & 3.302 \\
\hline 5 & 3.95 & 0.643 & 6 & & & & 15 & 0.709 \\
\hline \multicolumn{9}{|c|}{ Treated with Long leaf extract } \\
\hline 1.25 & 4.22 & 0.657 & 10 & & & & 19 & 1.565 \\
\hline 2.5 & 4.33 & 1.37 & 8 & 3.81 & 0.543 & 11 & 17 & 1.15 \\
\hline 5 & 4.05 & 0.78 & 7 & & & & 16 & 0.77 \\
\hline \multicolumn{9}{|c|}{ Treated with Round leaf extract } \\
\hline 1.25 & 3.24 & 1.503 & 11 & & & & 22 & 3.776 \\
\hline 2.5 & 6.48 & 2.11 & 10 & 5.57 & 1.515 & 13 & 21 & 1.207 \\
\hline 5 & 8.11 & 1.224 & 6 & & & & 17 & 3.56 \\
\hline \multicolumn{9}{|c|}{ Treated with Cigarette extract } \\
\hline 1.25 & 3.51 & 1.34 & 11 & & & & 23 & 2.402 \\
\hline 2.5 & 4.60 & 1.095 & 10 & 4.99 & 1.66 & 14 & 22 & 0.646 \\
\hline 5 & 2.98 & 1.173 & 7 & & & & 19 & 2.862 \\
\hline
\end{tabular}

In general, the abnormalities induced include spindle disturbances like stickiness, somatic bridge formation, diplochromatid and clumping. These effects are expected in view of the known action of nicotine and its related substances on the disulphide and sulphydryl linkages which enter into spindle formation. Since these effects are principally at the subnarcotic levels, they are gradually lost as tissue recovers following treatment with lower dosages. The effects of tobacco extracts at dosages containing low nicotine are reversible for lower durations of treatment. There is a clear proportionality of the duration of treatment and concentration with abnormality. In no case however, $\mathrm{C}$-mitosis or $\mathrm{C}$-tumour formation could be recorded. This indicates that the effect is an immediate one which is lost gradually on recovery. Presumably the effect of the extracts on root tip cells is at the physico-chemical level. The absence of any breaks suggests the possibility that the action is entirely on the spindle formation and no chemical action takes place with the DNA or DNA-protein complex. Therefore, there appears to be no appreciable correlation between the effect of nicotine and changes at chromosomal or genic level in plant system. These data are in accordance with the known properties 
of nicotine (Wilkinson 1976). The harmful effects of nicotine have been observed on different metabolic pathways on spindle formation, due to its known preference for -SS- and -SHgroups (Tonge 1962). The four forms of tobacco tested by us were basically prepared by different processing methods. The general effects however, not significantly different and could be traced to their different nicotine contents. The mode of processing did not appear to make any appreciable change in their properties of affecting cell and chromosome division.

Table 2. Comparison between computed and actual table values of ' $t_{p}$ ' to find the range of levels of significance ( $p$ ) different tobacco extracts following Allium test

\begin{tabular}{|c|c|c|c|c|c|c|c|c|c|}
\hline \multirow{2}{*}{$\begin{array}{c}\text { Name of } \\
\text { leaf }\end{array}$} & \multirow{2}{*}{$\begin{array}{l}\text { Different } \\
\text { concen- } \\
\text { trations } \\
\text { used }(\mathrm{ppm}) \\
\end{array}$} & \multirow{2}{*}{$\begin{array}{l}\text { Calculated } \\
\text { values of " } t \text { " }\end{array}$} & \multirow{2}{*}{$\begin{array}{l}\text { Degrees } \\
\text { of } \\
\text { freedom }\end{array}$} & \multicolumn{5}{|c|}{ Tables values of ' $t_{p}$ ' } & \multirow{2}{*}{$\begin{array}{c}\text { Range of } \\
\text { significance } \\
\text { (for calculated } \\
\left.>^{\text {' }} t_{p}{ }^{\prime}\right)\end{array}$} \\
\hline & & & & $t_{0.10}$ & $t_{0.05}$ & $t_{0.025}$ & $\mathbf{t}_{0.01}$ & $t_{0,005}$ & \\
\hline \multirow[t]{3}{*}{ Bidi } & 1.25 & 4.47 & 19 & 1.328 & 1.729 & 2.093 & 2.439 & 2.861 & $0<\mathrm{p}<0.01$ \\
\hline & 2.5 & 3.302 & 18 & 1.330 & 1.734 & 2.101 & 2.552 & 2.878 & $0<\mathrm{p}<0.01$ \\
\hline & 5 & 0.709 & 15 & 1.341 & 1.753 & 2.131 & 2.602 & 2.947 & $\mathrm{p}>0.20$ \\
\hline \multirow[t]{3}{*}{ Long leaf } & 1.25 & 1.565 & 19 & 1.328 & 1.729 & 2.093 & 2.539 & 2.861 & $0.10<\mathrm{p}<0.20$ \\
\hline & 2.5 & 1.15 & 17 & 1.333 & 1.740 & 2.110 & 2.567 & 2.898 & $p>0.2$ \\
\hline & 5 & 0.77 & 16 & 1.337 & 1.746 & 2.120 & 2.583 & 2.921 & $\mathrm{p}>0.2$ \\
\hline \multirow[t]{3}{*}{ Round leaf } & 1.25 & 3.776 & 22 & 1.321 & 1.210 & 2.074 & 2.508 & 2.819 & $0<\mathrm{p}<0.01$ \\
\hline & 2.5 & 1.207 & 21 & 1.323 & 1.721 & 2.080 & 2.518 & 2.831 & $p>0.2$ \\
\hline & 5 & 3.56 & 17 & 1.333 & 1.740 & 2.110 & 2.567 & 2.898 & $0 \quad p>0.01$ \\
\hline \multirow[t]{3}{*}{ Cigarette } & 1.25 & 2.402 & 23 & 1.319 & 1.714 & 2.069 & 2.500 & 2.807 & $0.02<\mathrm{p}<0.05$ \\
\hline & 2.5 & 0.646 & 22 & 1.321 & 1.710 & 2.074 & 2.508 & 2.819 & $p>0.2$ \\
\hline & 5 & 2.862 & 19 & 1.328 & 1.729 & 2.093 & 2.539 & 2.861 & $0<p<0.01$ \\
\hline
\end{tabular}

* Ranges of 'p' are found out considering two-tail test.

Table 3. FISHER ' $t$ ' values for comparison between percentage of abnormal cells for various extracts

\begin{tabular}{|c|c|c|c|c|c|c|c|c|}
\hline \multirow{3}{*}{$\begin{array}{c}\text { Different } \\
\text { concentrations } \\
(\mathrm{ppm})\end{array}$} & \multirow{3}{*}{$\underset{\text { leaf }}{\text { Name of }}$} & \multirow{3}{*}{$\begin{array}{l}\text { Sl. } \\
\text { No. } \\
\text { (i) }\end{array}$} & \multirow{3}{*}{$\frac{\left(\sqrt{\left(\frac{1}{n_{1}}+\frac{1}{n_{j}}\right)}\right.}{\begin{array}{c}\text { Mean No. } \\
\text { of abnormal } \\
\text { cells } \\
\left(p_{1}\right)\end{array}}$} & \multicolumn{2}{|c|}{$\frac{\left(n_{1}-1\right) s_{1}^{2}+\left(n_{j}-1\right) s_{1}^{2}}{n_{i}+n_{j}-2}$} & \multicolumn{3}{|c|}{ for $\begin{aligned} \mathrm{i} \neq \mathrm{j}, \mathrm{i} & =1,2,3,4 \\
\mathrm{j} & =1,2,3\end{aligned}$} \\
\hline & & & & \multirow[b]{2}{*}{$\begin{array}{l}\text { No. of } \\
\text { readings } \\
\left(n_{1}\right)\end{array}$} & \multirow{2}{*}{$\begin{array}{c}\text { Standard } \\
\text { deviation } \\
\left(\mathrm{s}_{1}\right)\end{array}$} & \multicolumn{3}{|c|}{ Computed $t_{i j}$ values } \\
\hline & & & & & & $\begin{array}{l}\text { With } \\
\text { Bidi } \\
(\mathrm{j}=1)\end{array}$ & $\begin{array}{l}\text { With } \\
\text { round leaf } \\
(\mathrm{j}=2)\end{array}$ & $\begin{array}{l}\text { With } \\
\text { long leaf } \\
(\mathrm{j}=3)\end{array}$ \\
\hline \multirow{4}{*}{5} & Bidi & 1 & 3.54 & 6 & 0.312 & $x$ & $x$ & $x$ \\
\hline & Round leaf & 2 & 7.34 & 6 & 0.085 & 8.125 & $x$ & $x$ \\
\hline & Long leaf & 3 & 3.58 & 7 & 2.360 & 0.041 & 3.574 & $x$ \\
\hline & Cigarette & 4 & 5.02 & 7 & 3.080 & 1.159 & 2.558 & 0.979 \\
\hline \multirow{4}{*}{2.5} & Bidi & 1 & 2.80 & 9 & 2.613 & $x$ & $x$ & $x$ \\
\hline & Round leaf & 2 & 5.74 & 10 & 2.513 & 2.490 & $x$ & $x$ \\
\hline & Long leaf & 3 & 4.43 & 8 & 1.485 & 1.553 & 1.299 & $x$ \\
\hline & Cigarette & 4 & 4.21 & 10 & 2.525 & 1.196 & 1.358 & 0.217 \\
\hline \multirow{4}{*}{1.25} & Bidi & 1 & 1.65 & 10 & 0.728 & $x$ & $x$ & $x$ \\
\hline & Round leaf & 2 & 2.29 & 11 & 1.016 & 1.644 & $x$ & $x$ \\
\hline & Long leaf & 3 & 3.07 & 10 & 1.426 & 2.800 & 1.455 & $x$ \\
\hline & Cigarette & 4 & 2.35 & 11 & 0.914 & 1.927 & 0.145 & 2.711 \\
\hline
\end{tabular}

\section{Summary}

The mutachromosomal and mutagenic effects of water soluble extracts of different forms of tobacco preparations used in India, were observed on the plant system Allium cepa in vivo. 


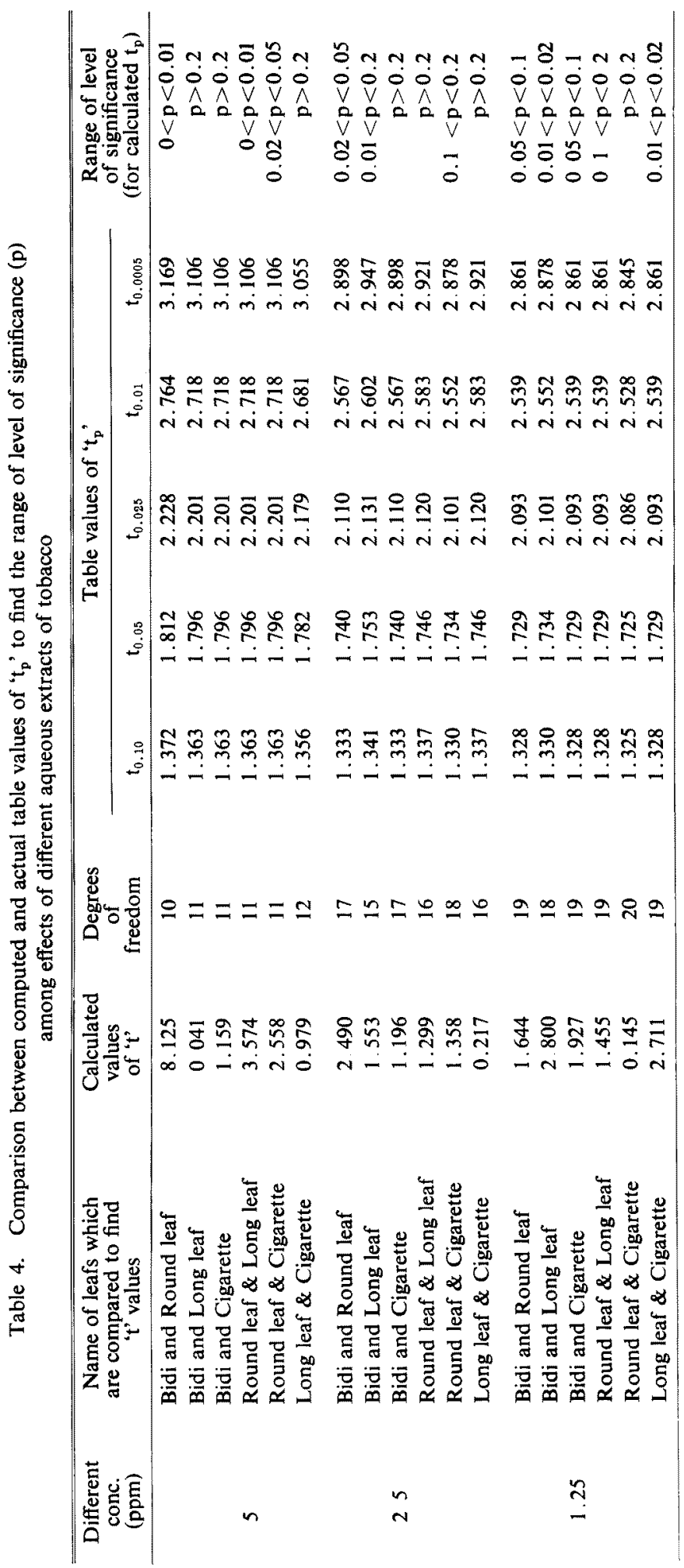


The four forms of tobacco tested prepared by different processing methods. Mitotic index indicated that certain concentrations of tobacco extracts were mitogenic in Allium cells. The abnormalities recorded were stickiness, somatic bridge formation, diplochromatid and clumping. The mode of processing did not appear to make any appreciable change in affecting cell and chromosome division.

Key Words: Tobacco extract, mitotic index, chromosomal abnormalities.

\section{Acknowledgement}

The author is thankful to her Superavisor Prof. A. Sharma, Professor of Genetics, Department of Botany, University of Calcutta for her guidance and to Prof. A. K. Sharma, Programme C-ordinator, Centre for Advanced Studies, for providing the facilities. Council for Scientific and Industrial Research is thankfully acknowledged for providing the Fellowship to the author.

\section{References}

Banerjee, A. and Sharma, A. 1979. Effect of tobacco extracts on Allium cepa chromosoms. Perspective in Cytol. and Gen. 3: 633-637.

Bandyopadhyay, A. and Sharma, A. 1980. Tobacco and its mutagenic effect. The nucleus 23: 157-169.

Grant, WF. 1982. Chromosome aberration assays in Allium. A report of the U.S. Environmental Protection Agency Genetox Programme. Mutat. Res. 99: 273-291.

IARC Monographs, 1989 . Tobacco habits other than smoking 37: 37-136.

Schmeltz, I. and D. Hoffmann, D. 1977. Nitrogen containing compounds in tobacco and tobacco smoke. Chem. Rev. 77: 295-311.

Shapiro, L. 1981. Warning-chewing tobacco and snuff may be dangerous to your health. Coal Age, 86: 7479.

Sharma, A. K. and Sharma, A. 1980. Chromosome Techniques-Theory and practice. 3 edn. Butterworths, London.

Stedman, R. L. 1968. The chemical composition of tobacco and tobacco smoke. Chem. Rev., 68: 153-175.

Stich, H. F. and Stich, W. 1982. Chromosome damaging activity of saliva of betelnut and tobacco chewers. Cancer Lett. 15: 193-202.

— and Rosin, M. P. 1984. Micronuclei in exfoliated human cells as a tool for studies in Cancer risk and cancer invention. Cancer Lett. 22: 241-253.

Tonge, B. L. 1962. Effect of tobacco smoke condensate on the aryl oxidation of cysteine. Nature 194: $284-286$.

WHO Technical Report Series 1983. Smoking Control Stratigies in developing countries. WHO Geneva: 695.

Wilkison, C. F. 1976. Insecticide Biometry and Physiology. Plenum Press. New York. 